\title{
Todo muerde
}

\section{Carmen Ramírez}

El calor sofocaba al burro, "Chico", cuando se aceraron sus padres. Los padres de Chico eran dueños de una empresa grande de transportación y le pidieron a Chico que llevara un paquete a la casa de unos clientes muy especiales.

- Chico, este paquete es muy importante y necesitamos que llegue a tiempo-le dijeron sus padres. Entonces, Chico empezó su viaje de un día para poder llegar a tiempo.

El viaje de Chico comenzó muy fácil. El calor era el único obstáculo para Chico. Pero durante su viaje Chico encontró a sus amigos.

— ¡Oye Chico! ¿Qué haces por acá? ¡Vamos a comer con unas burras muy bonitas! ¡Ven con nosotros!le gritó su amigo Pepe. Chico de repente se sintió muy estresado. Sabía que necesitaba llevar el paquete a los clientes de sus padres. No sólo era un trabajo importante, pero también era una oportunidad para demostrarle a su mamá y a su papá que él era un buen trabajador. Entonces Chico le dijo a sus amigos que no los va a acompañar a la cena con las burras. Los amigos de Chico le hicieron burla por prestar tanta atención en un paquete.

- ¡Es solo un paquete! ¿Qué tan grande seria la consecuencia si no lo llevas?

— ¿Saben qué? Tienen razón-les dijo Chico a sus amigos.

Entonces, Chico salió con sus amigos y decidió olvidarse del paquete. Los clientes estaban muy enojados porque no les llegó el paquete y cortaron todo tipo de negocios con los padres de Chico. Esto dejó a los padres de Chico sin dinero.

Cuando Chico llegó a su casa al siguiente día, sus padres le contaron la situación. Chico tuvo entonces que vivir con las consecuencias de poner a su familia en deuda, sólo por querer salir con sus amigos. 